\title{
鼓膜穿孔治癒機転と細胞増殖因子
}

一文献的考察一

\author{
嶋田高 明
}

\section{Healing Process of Tympanic Membrane Perforation and Growth Factors}

\author{
- A Review of Literature- \\ Takaaki Shimada \\ (The University of Tokusima)
}

\begin{abstract}
Tympanic membrane perforation, among otic diseases, is an important condition often encountered in the routine outpatient clinic. There are many reports on experimental pathological study of animals trying to elucidate the healing process of tympanic membrane perforation. However, much remains to be clarified about the healing process and the various influencing factors.

In recent years, studies are reported using growth factors for tympanic membrane perforation. Some growth factors accelerate the healing of tympanic membrane perforation. Studies using growth factors have great potential for elucidating the healing process.
\end{abstract}

Key words: tympanic membrane, wound healing, growth factor

はじめに

耳疾患の中でも鼓膜穿孔は, 日常外来診療に おいて頻繁に経験される重要な病態である。そ の原因は，急性，慢性化膿性中耳炎などの炎症 性穿孔と直接外力または間接外力による外傷性 穿孔に分けられる，原因が何であれ，早期に穿 孔が閉鎖する症例もあれば，穿孔が閉鎖せず閉 鎖手術が必要となる症例も経験するところであ る.ヒトでは臨床的観察による推測しかできず, 鼓膜が創傷に対していかなる反応を示し，どの 様な治瘉過程をたどって行くかの解明は, 動物 を用いた実験病理学的研究に委ねられる. 1965 年 Taylor と McMinn ${ }^{1)}$ が鼓膜穿孔の治癒過程
における細胞学的変化を報告して以来，鼓膜穿 孔の治癒過程を明らかにするため, 種々の動物 を用いた実験病理学的研究に関する多くの報告 がある2) 24). しかし，鼓膜穿孔の治瘉過程お よびそれに及ぼす種々の影響因子については未 だ不明な点が多い，近年，創傷治癒に関与する ことが示唆されている細胞増殖因子を鼓膜穿孔 に用いた研究報告が散見され21) 24), 新たな展 開を見せている。

そこで，今回実験的鼓膜穿孔の治癒過程およ びそれに影響を及ぼすであろら細胞増殖因子に ついて文献的考察を行い，この分野の現状把握 を行ってみた。 
実験的鼓膜穿孔作製法について

穿孔作製法はほとんどが機械的に鼓膜を破る ものであり，鈍な消息子(1) 315)10)，鼓膜切開 刀11117) 20), 針899113)24) 等によるものがある. 実験 的鼓膜穿孔に何らかの物質を作用させその影響 を比較検討するためには, 穿孔の大きさ, 辺縁 の状態を可及的に同一にすることが必要である. 老木 ${ }^{21)}$ は, この点を重要視し上記の方法では 穿孔の大きさを一定にできているとは言いがた く, さらに, 対象動物の豉膜は非常に薄く, 脆 弱なため, 穿孔辺縁の状態も均一にできていな いと指摘している．彼は，ニクロム線による焼 灼により穿孔を作成している。そして，この方 法によれば，(1)穿孔径をほぼ一定にできる，(2) 穿孔辺縁の状態が一定である, (2)同時に止血も できるため凝血塊などによるコンタミネーショ ンがない，(4)手技上の熟練を要しない，(5) 1 回 の操作でごく短時間に行える, などの利点を挙 げている，他に電気焼灼法を用いたものとして Söderberg ら ${ }^{16)}$ の報告がある. 彼らは切開刀に よる鼓膜穿孔と電気焼灼によるものとの比較検 討を行い, 電気焼灼法によるものは, 切開刀に よるものより穿孔閉鎖が遷延すると報告してい る. その理由として，穿孔作製後の穿孔縁が中 間層であり, 穿孔治瘉早期に反応を示寸表皮層 でなかったこと，ツチ骨柄の血管が穿孔作製後， 9 日目まで見出せず血流がそしかったことを挙 げている，焼灼による鼓膜穿孔治瘉過程は機械 的損傷によるものとは少し異なるようである.

しかし, 種々の条件による治癒の变化を比較検 討するモデル作製には，非常に有益な手段の一 つと考えられる。

\section{鼓膜穿孔の自然治癒過程について}

鼓膜穿孔の治癒過程が一般の創傷治瘉過程と 大きく異なる点は, 穿孔のため生じた下床のな い間隙を埋めなければならないといら点である。 豉膜穿孔の治癒過程については, 中間層の増生 した肉芽により穿孔が閉鎖され，その土台の上 に上皮が移動定着するといら説と, 表皮層の扁 平上皮過形成がまず穿孔を閉鎖するといら説と
の二つに分けられる．動物実験でその治癒過程 を形態学的に検討した報告は多く，その結果は 前者を支持する者(1) 3) より後者(6)899)11113)15)を支 持する者の方が多い。

穿孔治癒過程に拈ける細胞増殖活性について は, オートラジオグラフィーによる観察報告が ある2138)(9)13). Taylor と McMinn ら 223) は穿孔後 10時間頃より表皮層の細胞は分裂増殖を始め, その増殖活性は穿孔後48時間でピークをむかえ る.また，穿孔縁から離れた周囲の細胞にも増 殖活性を認め，互いに厚くなった穿孔縁を押し つけ治癒を助けていると報告している. Reijnen $5^{8)}$ は穿孔後 2 日目で穿孔に近い鼓膜輪と ッチ骨柄で著明に増殖活性が増し, その後は穿 孔に向かって増殖活性の範囲が広がる。そして 穿孔閉鎖後, 増殖活性は速やかに減少すると報 告している. 鼓膜各層の細胞増殖動態を知るこ とは，鼓膜穿孔の治癒過程を一層明らかなもの にすると考えられる。

鼓膜穿孔の治癒過程を論じる時, 上皮の移動 (migration) の問題がある. 文献的には1964年 の Alberti25)の報告がよく知られている. 彼は, 鼓膜表皮に色素を点状に塗布して, migration を詳細に検討している，鼓膜の migration の中 心は鼓膜臍あるいはツチ骨柄にあり, 鼓膜表皮 はその中心部から鼓膜周辺部さらに外耳道へと 放射状に移動する. 外耳道壁から鼓膜へ向から ことはないし, 鼓膜の周辺部から中心部へ向か らこともないと述べている. migration の発生 機序については, Litton' ${ }^{26)}$ がオートラジオグラ フィーを用いた実験的研究で, 鼓膜の migration の原動力は鼓膜表皮に抢ける generation center と他の部位との増殖力の差により生ず るとしている. 鼓膜, 外耳道皮膚の migration は, 種々の鼓膜, 外耳道抢よび中耳病变により 障害される27)。また病的鼓膜では, migration の速度低下および異常パターンを認めるという 報告がある ${ }^{28)}$. 鼓膜穿孔の閉鎖に migration が関与しているとする報告は多い，他の諸因子 の存在に加えて, migration が穿孔閉鎖の一つ 
の重要な因子であると思われる.

鼓膜穿孔に対する薬剤の影響について 鼓膜穿孔部に薬剤を作用させその影響を検討 したものは少ない. Rogers ら4)はフェノール， マイトロジェンマスタード等を作用させ永久穿 孔の作成を試み，Fry 5 ${ }^{14)}$ は点耳薬の鼓膜穿 孔に及ぼす影響を検討しているが，いずれも鼓 膜穿孔の治癒過程は明らかにされていない。

1985年 Stenfors ら ${ }^{17)}$ がヒアルロン酸を作用 させその影響を検討し, Hellström ら ${ }^{19)}$, Laurent ら 20)，が追及報告している。ヒアルロン酸は細 胞外マトリックスの一つであり，発生や損傷修 復の過程のように細胞が盛んに移動する組織に おいて特別な機能を持つと言われている29). 鼓 膜穿孔治癒過程に扣いても有利に働くことが示 唆されている.

最近になって鼓膜各層に影響を持つであろう 細胞増殖因子を用いた研究が報告されている. すなわち老木 ${ }^{21)}$ は上皮成長因子 (epidermal growth factor ; EGF), ヒ上腫瘍細胞増殖因子

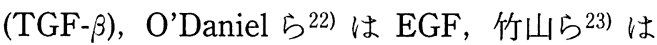
血小板由来成長因子 (PDGF), Mondain 5 24) は 線維芽細胞増殖因子 (FGF) を用いて鼓膜穿孔 の治瘉過程に执ける各々の増殖因子の影響を検 討している. 各々の増殖因子については次の項 で詳述する. EGF は鼓膜の上皮細胞の増殖, 進展を促進させ，中間層に対してはむしろ増殖 抑制的に働く傾向がある21). 鼓膜穿孔の閉鎖を 有意に早める2122)。鼓膜には EGF と高い親和 性を示すリセプターが存在する22). TGF- $\beta$ は 鼓膜の上皮細胞の増殖進展を軽度抑制し, 中間 層に打いても増殖抑制的に働く. 結果として, 鼓膜穿孔の治癒に対しては抑制的に働く傾向が ある21). 竹山ら ${ }^{23)}$ は老木との一連の研究に执い て, PDGF は EGFよりもさらに治瘉促進的に 働くと報告し, PDGF が早期より中間層の肥厚 を促す可能性があることを示唆している. FGF は鼓膜穿孔の閉鎖を早める. 治瘉過程に おける経過は自然治瘉過程とほぼ同様である。 高濃度の FGF は鼓膜炎の若起する可能性が高
(24)。以上，増殖因子を用いた研究は鼓膜穿孔 の治癒過程解明に大きな一助となる可能性があ り，さらなる詳細な報告が待たれる。

\section{細胞増殖因子について}

増殖因子 (growth factor) は in vivo, in vitro において，動物細胞の成長を促進するものであ って，栄養物質ではないものと定義されてい る30).ここでいう栄養物質とは，細胞内に入 って代謝基質，または補酵素として利用される もののことである. 現在, 増殖因子と呼ばれて いるものは非常な多数にのぼっている.これら の増殖因子のうち鼓膜穿孔治瘉過程との関連が 示唆されている FGF, EGF, PDGF, TGFにつ いて最近の知見を紹介する.

1. FGF（線維芽細胞増殖因子）

1974年, Gospodarowicz ${ }^{31)}$ はウシ下垂体から 線維芽細胞の増殖を強く刺激する分子量約 17,000の蛋白質を見い出し FGF と命名した. 遺伝子がクローニングされた結果，アミノ酸配 列の相同性より FGF ファミリーは現在のとこ ろ aFGF, bFGF, INT2, HST1, FGF5, HST2, $\mathrm{KGF}$ の 7 つの遺伝子産物が知られている。増 殖因子としての活性を指標に得られたもの， ウ イルスが挿入したときに活性化される細胞側遺 伝子として得られたもの，トランスフォーミン グ遺伝子として得られたもの，またそれと相同 性を有する遺伝子として得られたものなど，そ の分離，同定のされ方は様々であるが，これら の蛋白質のらちほとんどのものは増殖因子とし ての活性を示し，また強弱はあるにせよトラン スフォーミング活性を示す。また，これらの増 殖因子群はへパリンに結合する能力あるいは結 合する特異的なアミノ酸配列をもっており， へ パリン結合増殖因子群ともいえる ${ }^{32)}$ 。これら $\mathrm{FGF}$ ファミリーのうち増殖刺激活性の強力な bFGF について詳解する。

bFGF は分子量約 17,000, 等電点9.6の塩基 性単鎖ポリペプチドで, 酸性条件や60度以上の 熱処理で失活する33)34)。 bFGF は線維芽細胞ば かりでなく血管内皮細胞，血管平滑筋細胞，角 
膜内皮細胞，骨芽細胞，軟骨細胞など多種の細 胞に対する細胞増殖を刺激することが明らかに されている35)。また血管内皮細胞の遊走，内皮 細胞からの urokinase-plasminogen activator 産 生を促進し in vivo で強力な血管新生作用を有 することも報告されている36)。細胞増殖作用, 血管新生作用，コラーゲン産生促進作用を示す 結果 in vivo で肉芽形成を刺激する. 更に，ヶ ラチノサイトの増殖，遊走を促進することも報 告され，再上皮化に関与していることが示唆さ れている37). bFGF は生体内で, 下垂体, 網膜, 黄体, 前立腺, 胎盤, 軟骨, 骨など広範な組織 飞分布している38)。組織中 bFGF は, 細胞外、 トリックス成分の一つであるへパリンに結合し た形で存在し，損傷部位に集積した炎症細胞が 分泌する酵素などにより遊離し損傷部位の修復 に寄与することが示唆されている39). 以上, bFGF は創傷治癒過程において重要な細胞増殖, 遊走, 血管新生, 肉芽形成, 再上皮化, いずれ の反応も促進する.

\section{EGF（上皮成長因子）}

Cohen ${ }^{40)}$ は雄マウス顎下腺中の神経成長因子 (nerve growth factor；NGF) を精製する過程で, 顎下腺抽出物を新生児マウスに投与したところ， 眼瞼開裂掞よび切歯出現が早期に起こることに 気付き，歯瞼因子 (toothlid factor) と名付けた. 後に彼はこの作用が上皮細胞の顕著な増殖と, それに伴う角化に基づくことを組織学的に明ら かにし，1964年この因子を epidermal growth factor (EGF) とあらためて命名した ${ }^{41)}$. 1975年 Cohen と Carpenter ${ }^{42)}$ は，ヒト尿中にも EGF が存在することを発見し，ヒト EGF (hEGF) を精製に成功している. 一方，これとは別に Gregory ${ }^{43)}$ は，強力な胃酸分泌抑制物質の $\beta-$ ウロガストロン (UG) をヒト尿から単離, 同定 した. $\beta$-UG とマウス EGF (mEGF) の一次構造 は極めて類似し，乙かも両者は共通の生物作用， すなわち $\mathrm{EGF}$ が胃酸の分泌を抑制し, $\beta-\mathrm{UG}$ が新生児マウスの眼瞼開裂を早期に起こすこと から，彼は両者が同一種類の物質であろらと報
告した。 以来, $\mathrm{EGF} / \mathrm{UG}$ と総称されて現在に 至っている44).

hEGF は分子量6,021，等電点4.5で，53個の アミノ酸からなるペプチドである. EGF の作 用は極めて広範囲にわたり，また種特異性が少 ない44)45). EGF は上皮系細胞にとどまらず, 各種の培養細胞に対して強い増殖作用を示す. すなわち各種の線維芽細胞, 軟骨細胞, 平滑筋 細胞, 乳腺上皮細胞, 甲状腺細胞, 肝細胞, グ リア細胞等の DNA 合成や細胞增殖を $\mathrm{ng} / \mathrm{ml}$ の 濃度で促進する。しかし多くの場合, EGF 単 独の作用はわずかでありインシュリン, IGF-I, レチノール酸, アスコルビン酸などは相乗的に その作用を増強する ${ }^{46)}$. hEGF は顎下腺, 十二 指腸, 甲状腺, 膵, 上部空腸, 腎などに存在し ていることが知られており, 免度組織学的にも その局在が証明されている。しかし，その濃度 はマウス顎下腺と比べると極めて低值で, ヒト における真の hEGF 産生部位は現在なお明ら かではない47). hEGF は尿, 血漿, 唾液, 䯣液, 乳汁などほとんどすべての体液に含まれてい る48). おちとら hEGF 産生細胞は全身に広く 分布し，パラクリン系細胞と同じように，局所 ホルモン様物質として合成, 分泌されている可 能性がある. EGF の作用は, 標的細胞の細胞 膜に存在する特異的 EGF リセプターと結合す ることから発現する. EGF リセプターは分子 量約170,000の糖タンパクである ${ }^{49)}$. 遺伝子工 学的に大量の $\mathrm{EGF}$ が入手可能となり, 合成 EGF の治癒への試みがなされている50).

\section{PDGF（血小板由来成長因子）}

Balk $^{51)}$ は， ニワトリ胚正常細胞が低カルシ ウム条件下で, 血漿添加培地ではほとんど増殖 しないが，血清添加培地では活発に増殖するこ とを観察した. Kohler ら52) は, 単離したヒト 血小板からマウス $3 \mathrm{~T} 3$ 細胞の増殖を促進する 物質を見出した。同じ頃，サル動脈の平滑筋細 胞の増殖を研究していた Ross ら ${ }^{53)}$ は，血清添 加培地では増殖促進作用が著しく低いことを観 察した。一方, Antoniades ら54) は, ヒト血清 
からインシュリン様活性をもたないが，マウス 3T3 細胞の增殖促進作用を示す因子を精製した. ラジオイムノアッセイにより，この因子が血小 板に多量に含まれていることがわかった．以来， この血小板中に存在し，血清の調整過程で血清 中に移行し, 線維芽細胞, 平滑筋細胞, グリア 細胞などの増殖を促進する因子を PDGF と呼 ぶようになった。

PDGF は分子量約 30,000 , 等電点 9.8 のペプ チドである. 分子量 18,000 の $\mathrm{A}$ 鎖と分子量 16,000のB鎖から成り立って扣り， A-Bのへ

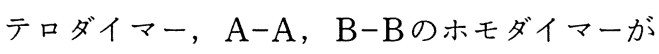
存在する55)56). PDGF は, 血小板の細胞小器官 である $\alpha$-顆粒中に, 幾種類かの他のペプチド とともに貯蔵されている57). 現在では血小板以 外にもマクロファージ，血管壁の内皮細胞, 平 滑筋細胞のいずれもが PDGF を産生すること が知られている ${ }^{48)}$. PDGF は線維芽細胞, グリ

ア細胞, 平滑筋細胞などの中肧葉由来の細胞に 作用する。 その作用は FGF と類似し，休止期 の細胞に作用し適格状態 (competence) とする.

しかし，これだけでは細胞は細胞周期を進行せ ず，さらに周期を進行 (progression) させるた めにはインシュリン, IGF-I など progression factor が必要である46). 従来は PDGF は内皮 細胞や上皮由来の細胞には作用しないものと考 えられていたが, 現在では, 場合によってはど ちらの細胞にも作用することが確かめられてい る. PDGF の体の中での働きを理解するらえ で重要なのは細胞の遊走促進作用である. PDGF は線維芽細胞や平滑筋細胞, 好中球, 単球などに作用してその遊走を促進する ${ }^{48)}$. こ の作用により間接的に細胞増殖活性を高めると 考えられている.

4. TGF (トランスフォーミング成長因子)

TGF の研究は1978年の sarcoma growth factor (SGF) の発見に始まる58). Todaro らのグ ループは Molony 肉腫ウイルスで形質転換した マウス $3 \mathrm{~T} 3$ 細胞が, その培養無血清培地中に 正常細胞を悪性細胞様に転換させる作用をもつ
因子を多量産生していることを報告した。その 後, 各腫の腫瘍細胞からもそのような作用を示 す物質が見い出され，SGFを含めこの作用を 示す物質をすべて包括して TGF と呼ぶように なった。ところがさらに検索が進んだ結果, TGF 活性を有する物質は正常組織や胎児その 他からも見い出され，今日では TGF は必ずし も腫瘍に特異的なものとはいえなくなってい

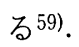

TGF は分子量を異にするいくつかの分子種 が報告されて拈り, 現在は $\alpha, \beta, \gamma$ のつに分 類されている46).

TGF- $\alpha$ は分子量約 7,000 のペプチドであり， 各種の腫瘍細胞の培養メジウム, 抽出物中に存 在する.TGF- $\alpha$ はその構造が EGF と極めて類 似しており，EGF の受容体と結合しらる60). TGF- $\alpha$ の作用の発現は EGF の受容体を介する ものと考えられるが，それだけでは十分ではな い. EGF 自体には TGF 活性がないからであ る46). EGF の結合部位以外にも TGF- $\alpha$ との結 合部位が存在するとの報告がある61).

TGF- $\beta$ は分子量約 25,000 のペプチドであ る62). TGF- $\beta$ は腫瘍組織の他活とんどすべて の正常組織中に存在する。ヒトでは血小板 ${ }^{58)}$, 胎盤63) に多量に含まれている. TGF- $\beta$ は独自 の受容体を有し各種の標的細胞に同定されてい るが，その物理化学的性質は未だ不明である.

TGF- $\beta$ は細胞の種類や，ともに添加する他の 成長因子の種類によっては細胞増殖を抑制する (bifunctionality) $^{64)}$. したがって，TGF- $\beta$ は細 胞増殖の regulator ではないかとの仮説も提唱 されている.

一方, $\alpha, \beta$ に属さない新しいタイプの TGF- $\gamma$ の存在が明らかにされている. TGF- $\gamma$ は EGF の受容体と結合する作用はなく，かつその TGF 活性の発現に EGF の存在を必要としない46).

以上 3 種類の TGF は正常細胞に作用する軟 寒天培地での増殖, すなわち anchorage-independent growth を炭起する特異的な一群の 増殖因子である。 


\section{まとめ}

1 ）鼓膜穿孔治癒機転について, 実験病理学 的研究を中心に文献的に考察した。

2 ）鼓膜穿孔治癒機転との関連が示唆されて いる細胞増殖因子について文献的に考察した.

3 ）鼓膜の各層に特異的に影響する物質を作 用させることにより，穿孔治癒の促進や，穿孔 閉鎖不全の予防に役立つよらな詳細な知見を得 られる可能性がある.

稿を終えるにあたり，御校閲を頂いた徳島大学医 学部耳鼻咽喉科学教室小池靖夫教授に深謝致します.

\section{参考文献}

1) Taylor $M$ and McMinn RMH : Healing of experimental perforations of the tympanic membrane. J Laryngol Otol $79:$ 148 158, 1965.

2) McMinn RMH and Taylor $M:$ The cytology of repair in experimental perforations of the tympanic membrane. Br J Surg 53 : 222 232, 1966.

3) Taylor $M$ and McMinn RMH : Cytology of repair in experimental perforations of the tympanic membrane and its relationship to chronic perforations in man. Tr Am Acad Ophth Otol $71: 802 \sim 812,1967$.

4) Rogers KAJr and Snow JBJr : Closure of experimental tympanic membrane perforations. Ann Otol Rhinol Laryngol 77 : 66 71, 1968.

5）稲川俊文：鼓膜穿孔に関する臨床的並びに実験 的研究. 日耳鼻 $72: 687 \sim 718,1969$.

6) McIntire $C$ and Benitez JT : Spontaneous repair of the tympanic membrane; histopathological studies in the cat. Ann Otol Rhinol Laryngol 79 : 1129 1131, 1970.

7) Hildmann $\mathrm{H}$ and Steinbach E : Experimental studies on closing of artifical eardrum perforations in rabbits. J Laryngol Otol 85 : 1173 1176, 1971.

8) Reijnen CJH and Kuijpers $W$ : The healing pattern of the drum membrane. Acta Otolaryngol (Stockh) Suppl $287: 1 \sim 74,1971$.

9) Clowson JP and Litton WB : The healing process of tympanic membrane perforations. $\mathrm{Tr}$ Am Acad Ophth Otol 75 : 1302 1312, 1971.
10) McMinn RMH : Electron microscopic observations on the reipar of perforated tympanic membranes in the guinea pig. J Anat $120: 207 \sim 217$, 1975.

11) Reeve DRE : Repair of large experimental perforations of the tympanic membrane. $\mathrm{J}$ laryngol Otol $91:$ :767 778, 1977.

12) Boedts D and Ars B : Histopathological research on eardrum perforations. Arch Otorhinolaryngol $215: 55 \sim 59,1977$.

13) Boedts $D$ : The tympanic epithelium in normal and pathological conditions. Acta Otorhinolaryngol Belg $32:$ 296 419, 1978.

14) Fry TL, Chen B, Fischer ND, et al : Evaluation of otic drops on infection and healing of traumatic tympanic membrane perforations. Laryngoscope $89: 818 \sim 821,1979$.

15) Stenfors LE, Calsöö $B$, Salén $B$, et al : Repair of experimental tympanic membrane perforations. Acta Otolayngol (Stockh) $90: 332 \sim 341$, 1980.

16) Söderberg O, Hellström S and Stenfors LE : The healing pattern of experimental heat myringotomy. Rev Laryngol Otol Rhinol (Bord) $106: 81 \sim 85,1985$.

17) Stenfors LE, Berghem L, Bloom GD, et al : Exogenous hyaluronic acid (Healon $\left.{ }^{\mathbb{B}}\right)$ accelerates the healing of experimental myringotomies. Auris Nasus Larynx 12 Suppl 1: s214 s215, 1985.

18）朴 茂男: 実験的鼓膜切開創の修復過程に関寸 る電子顕微鏡的観察. 日耳鼻 $89: 843 \sim 853$, 1986.

19) Hellström $S$ and Laurent $C:$ Hyaluronan and healing of tympanic membrane perforations ; an experimental study. Acta Otolaryngol (Stockh) Suppl $442:$ 54 61, 1987.

20) Laurent $C$, Hellström $S$ and Fellenius $E$ : Hyaluronan improves the healing of experimental tympanic membrane perforations. Arch Otolaryngol Head Neck Surg $114: 1435 \sim 1441$, 1988.

21）老木浩之：モルモット鼓膜穿孔の治癒過程にお ける細胞成長因子の影響. 近畿大医誌 14:485 
$\sim 499,1989$.

22) O'Daniel TG, Petitjean M, Jones SC, et al : Epidermal growth factor binding and action on tympanic membranes. Ann Otol Rhinol Laryngol $99: 80 \sim 84,1990$.

23）竹山 豊, 老木浩之, 村田清高, 他 : モルモッ 卜鼓膜穿孔の治瘉過程における血小板由来成長 因子 (PDGF) の影響. Otol Jan 1: 164, 1991.

24) Mondain $M$, Saffiendine $S$ and Uziel $A$ : Fibroblast growth factor improves the healing of experimental tympanic membrane perforations. Acta Otolaryngol (Stockh) $111: 337 \sim$ 341, 1991.

25) Alberti PW : Epithelial migration on the tympanic membrane. J Laryngol $78: 808 \sim 830$, 1964.

26) Litton WB : Epithelial migration in the ear. Acta Otolaryngol (Stockh) Suppl $240: 1 \sim 39$, 1968.

27) Saad EF : The epidermis of the drumhead in some otologic conditions. Arch Otolaryngol $103: 387 \sim 388,1977$.

28) Makino $\mathrm{K}$ and Amatsu $\mathrm{M}$ : Epithelial migration on the tympanic membrane and external canal. Arch Otorhinolaryngol $243: 39 \sim 42$, 1986.

29) Laurent TC and Fraser JRE : The properties and turnover of hyaluronan. In Functions of the Proteoglycans (ed by Evered D and Whelan J). pp 9 29, Ciba Foundation, New York, 1986.

30) Gospodarowicz D and Moran JS : Growth factors in mammalian cell culture. Ann Rev Biochem 45 : 531 558, 1976.

31) Gospodarowicz D : Localisation of a fibroblast growth factor and its effect alone and with hydrocortizone on 3T3 cell growth. Nature $249: 123 \sim 127,1974$.

32）坂本裕美：ヘパリン結合性増殖因子フ ァミリー の構造と機能. 実験医学 $1: 19 \sim 24,1992$.

33）加藤洋一 : Fibroblast Growth Factor. 細胞成 長因子（日本組織培養学会編）。31～39頁，朝 倉書店, 東京, 1984 .

34）菅 幹雄 : Fibroblast Growth Factor. 細胞成 長因子 part 2 (日本組織培養学会編). 15～20
頁, 朝倉書店, 東京, 1987.

35) Gospodarowicz D, Ferrara N, Schweigerer L, et al : Structual characterization and biological functions of fibroblast growth factor. Endcrinol Rev 8 : 95 114, 1987.

36) Saksela O, Moscatelli D and Rifkin DB : The opposing effect of basic fibroblast growth factor and transforming growth factor beta on the regulation of plasminogen activator activity in capillary endothelial cells. J Cell Biol 105 : 957 〜963, 1987.

37) O'Keefe EJ, Chiu ML and Payne RE Jr: Stimulation of growth of keratinocytes by basic fibroblast growth factor. J Invest Dermatol $90: 767 \sim 769,1988$.

38) Baird A, Esch F, Mormède $P$, et al : Molecular characterization of fibroblast growth factor; distribution and biological activities in various tissues. Recent Prog Horm Res 42 : 143 205, 1986.

39) Baird A and Ling N : Fibroblast growth factors are present in the extracellular matrix produced by endothelial cells in vitro; implications for a role of heparinase-like enzymes in the neovascular response. Biochem Biophys Res Commun $142:$ 428 435, 1987.

40) Cohen $\mathrm{S}$ : Isolation of a mouse submaxillary gland protein accelerating incisor eruption and eyelid opening in the new-born animal. J Biol Chem 237 : 1555 1562, 1962.

41) Cohen $\mathrm{S}$ : Isolation and biological effects of an epidermal growth-stimulating protein. Metabolic Control Mechanisms in Animal Cells (ed by Rutter WJ). pp 13 27, National Cancer Institute, Meryland, 1964.

42) Cohen $S$ and Carpenter G : Human epidermal growth factor; isolation and chemical and biological properties. Proc Natl Acad Sci USA $72: 1317 \sim 1321,1975$.

43) Gregory $H$ : Isolation and structure of urogastrone and its relationship to epidermal growth factor. Nature $257: 325 \sim 327,1975$.

44）平田結喜緒 : Epidermal Growth Factor. 細胞 成長因子（日本組織培養学会編）．20～30頁， 
朝倉書店, 東京, 1984.

45）今井康雄 : Epidermal Growth Factor. 細胞成 長因子 part 2 (日本組織培養学会編). 10 15 頁, 朝倉書店, 東京, 1987.

46）封馬敏夫：成長因子. ホルモンと臨 33:1105 $\sim 1111,1985$.

47) Hirata $Y$ and Orth DN : Epidermal growth factor (urogastrone) in human tissues. J Clin Endocriol Metab $48: 667 \sim 672,1979$.

48）宮園浩平 : 増殖因子のプロフィール. 細胞増殖 因子のバイオロジー (一戸裕子編). 32〜69頁, 羊土社, 東京, 1922 .

49) Carpenter G, King LJr and Cohen S : Epidermal growth factor stimulates phosphorylation in membrane preparations in vitro. Nature $276: 409 \sim 410,1978$.

50）高久史榣 : 増殖因子の臨床応用; 現状と展望. 蛋白質核酸酵素 $36: 1406 \sim 1410,1991$.

51) Balk SD : Calcium as a regulator of the proliferation of normal but not of transformed chicken fibroblasts in a plasma-containing medium. Proc Natl Acad Sci USA 68 : 271 275, 1971.

52) Kohler $\mathrm{N}$ and Lipton $\mathrm{A}$ : Platelets as a source of fibroblast growth-promoting activity. Exp Cell Res $87: 297 \sim 301,1974$.

53) Ross, R, Glomset JA, Kariya B, et al : A platelet-dependent serum factor that stimulates the proliferation of arterial smooth muscle cells in vitro. Proc Natl Acad Sci USA 71 : 1207 1210, 1974.

54) Antoniades HN, Stathakos D and Scher CD : Isolation of a cationic polypeptide from human serum that stimulates proliferation of $3 \mathrm{~T} 3$ cells. Proc Natl Acad Sci USA 72 : 2635 2639, 1975.

55）加治和彦 : Platelet-derived Growth Factor. 細 胞成長因子（日本組織培養学会編）。44～53頁,
朝倉書店, 東京, 1984.

56）加治和彦: Platelet-derived Growth Factor. 細 胞成長因子 part 2（日本組織培養学会編）. 20 ～25頁, 朝倉書店, 東京, 1987.

57) Kaplan DR, Chao FC, Stiles CD, et al : Platelet alpha-granules contain a growth factor for fibroblasts. Blood 53 : 1043 1052, 1979.

58) DeLarco JE and Todaro GJ : Growth factors from murine sarcoma virus transformed cells. Proc Natl Acad Sci USA 75 : 4001 4005, 1978.

59）梅田 誠: Transforming Growth Factor. 細 胞成長因子（日本組織培養学会編）. 99～105頁, 朝倉書店, 東京, 1984.

60) Marquardt H, Hunkapiller MW, Hood LE, et al : Rat transforming growth factor type 1 ; structure and relation to epidermal growth factor. Science $223:$ 1079 1082, 1984.

61) Massague J, Czech MP, Iwata K, et al : Affinity labeling of a transforming growth factor receptor that does not interact with epidermal growth factor. Proc Natl Acad Sci USA 79 : 6822 6826, 1982.

62) Assoian RK, Komoriya A, Meyers CA, et al : Transforming growth factor-beta in human platelets. J Biol Chem 258 : 7155 7160, 1983.

63) Frolik CA, Dart LL, Meyers CA, et al : Purification and initial characterization of a type beta transforming growth factor from human placenta. Proc Natl Acad Sci USA $80: 3676 \sim 3680,1983$.

64) Roberts AB, Anzano MA, Wakefield LM, et al : Type beta transforming growth factor; a bifunctional regulator of cellular growth. Proc Natl Acad Sci USA 82 : 119 123, 1985.

$$
\left(\begin{array}{l}
\text { 別刷請求先 : 嶋田高明 } \\
\text { 干770 徳島市蔵本町2-50-1 } \\
\text { 徳島大学医学部耳鼻咽喉科学教室 }
\end{array}\right)
$$

